\title{
MARITIME VIOLENCE : IMPLICATIONS TO MALAYSIA
}

\author{
Nurulizwan Ahmad Zubir \& Wan Siti Adibah Wan Dahalan
}

The Faculty of Law, Universiti Kebangsaan Malaysia

Email:wsa@ukm.my

Tel: 0389216381, Faks: 0389253217

\begin{abstract}
Maritime Piracy has been a serious threat to the international community especially in the Southeast Asia region. This threat has caused tremendous implications towards the world economy, environment, political stability of the nations involved because 45\% of the shipping company passes through the Southeast Asia. The worrying fact is that these attacks were committed by terrorists as well as traditional maritime pirates. This paper examines on the implications of maritime crime in Malaysia and discusses whether the definition of piracy under the International Law could be applied to these attacks. This paper concludes that cooperation between the region's states and the enhancement of a good security system of one state are needed to combat maritime violence. Thus it is imperative that the international law need to be changed in order to enhance the meaning of piracy and also to include sea terrorism.
\end{abstract}

Keyword: Piracy, Maritime, Terrorist

\section{INTRODUCTION}

The first act of terrorism at sea occurred on the Italian cruise ship Achille Lauro in 1985, which had extensive press coverage, were not considered to be piracy. The event involved 4 armed Palestinian terrorists in October hijack the Italian cruise ship Achille Lauro, carrying more than 400 passengers and crew, off Egypt. The hijackers demand that Israel free 50 Palestinian prisoners. The terrorists kill a disabled American tourist. After a two-day drama, the hijackers surrender in exchange for a pledge of safe passage. But when an Egyptian jet tries to fly the hijackers to freedom, U.S. Navy F-14 fighters intercept it and force it to land in Sicily. The terrorists are taken into custody by Italian authorities.

Articles 100 to 107 and 110 of United Nations Convention on Law of the Sea ("UNCLOS"). Article 101 UNCLOS defines piracy as- (a) any illegal acts of violence or detention, or any act of depredation, committed for private ends by the crew or the passengers of a private ship or a private aircraft, and directed:

(i) on the high seas against another ship or aircraft or against persons or property on board such ship or aircraft;

(ii) against a ship, aircraft, persons or property in a place outside the jurisdiction of any State;

(b) any act of voluntary participation in the operation of a ship or of an aircraft, with knowledge of the facts making it pirate ship or aircraft;

(c) any act inciting or of intentionally facilitating an act described in subparagraph (a) or (b).

It goes without saying that the UNCLOS anti piracy regime defined that piracy is jure gentium (i.e. in international law) cannot occur in territorial sea, internal water and archipelagic waters of states $^{1}$.

From the UNCLOS definition of piracy, without the express permission of the coastal states, foreign powers cannot use their own forces to combat the maritime threats within the region. What happen if criminal acts do occur within the territorial sea and the internal water?

1 J. Chenevier's Article, 'Piracy under Law of the Sea Convention: conceptual basis and practical limitation.' 
Such acts do not fall under the definition of piracy under UNCLOS and thus the rule of international law relating to piracy is not applicable mutatis mutandis to such acts or incident.

In the case where some forms of violence conducted in the territorial sea as well as without the involvement of two ships, such as, for instance, the violent taking of control of a ship by members of its crew or passengers, even when the follow-up consists of holding to ransom the ship and its crew and passengers, are not included under the definition of 'piracy'.

Nevertheless, the acts of marine terrorism are often related to piracy due to the similarities encompass those two crimes. Both piracy and terrorist are viewed as a 'common enemy' to all humankind and involved coordinated attacks. The difference would only be the intent behind such acts which piracy acts involved intention to commit crime for private purpose while terrorism is motivated by political or religious belief to commit such. Although the goals and pirates and terrorists appear to be different the implications to the environment could be similar-destruction due to toxic oil and other types of pollution ${ }^{2}$ as well as the other implications to the economic, political, legal and technology.

\section{THE IMPLICATIONS of MARINE VIOLENCE TO MALAYSIA}

Amongst the reported cases of maritime piracy and armed robbery in the Malaysian water that has been reported by IMB in 'Weekly Piracy Reports' as of June 2000 are:-

1) A tanker hijacked in Malaysian waters in February 2000 has been recovered. According to the report, masked bandits armed with guns and swords had boarded the ship, which carried 6,000 metric tons of palm oil products, and blindfolded the crew before setting them adrift in a fishing boat with only basic provisions and making off with the ship. The ship was recovered at the end of May with approximately 2,500 metric tons of cargo still on board.

2) On June 8, 1999, pirates in two speedboats boarded and hijacked a ship off Tioman Island off the east coast of Malaysia. The ship was bound for Songkhla, Thailand, with 2,060 tons of gas oil. One member of the crew was held hostage, and the other 16 were placed in a lifeboat. Authorities in China eventually detained the ship.

IMB has reported that most of the maritime piracy occurred in the Straits of Malacca. This has caused concern to Malaysia being one of the coastal states guarding the Straits of Malacca as it would caused implications to Malaysia's in terms to our economy, politic, environment, legal and technology.

\section{Economic Implications}

Malaysia is the home to one of the busiest shipping lanes in the world (Malacca Straits). With two Malaysian major ports namely Port Klang and Port of Tanjung Pelepas which are located along the Straits of Malacca, the maritime violence issue will give negative impact in promoting these two ports as international transhipment hubs for containers traffic ${ }^{3}$. The attacks have caused economic implication to Malaysia whereby most of the foreign ships are not keen to stop at these two Malaysian ports as it will delay their journey and thus the risk to be attacked by the pirates is higher. Hence Malaysia lost their chance to collect its custom duty. Furthermore, costs of goods to the customer may have increased due to the losses directly incurred by the attack. Meaning to say, once attacked, the shipping company will incur the cost of the stolen cargo, or payment of ransom for crew and ship. There are also losses which arose due to the delays of goods due to the delays in port while the attack is being investigated and the replacement costs for the disrupted shipment. Therefore to absorb the increasing costs, the burden has been shifted or transferred to the customers by increasing the costs of the goods.

Another direct economic impact that exists with hotspots is the undermining of our trading ability. Maritime attacks within the jurisdiction make trading more expensive and therefore less favourable. As a result of this, it somehow damages the international relations with other countries because the issue of piracy was often

2 Leticia Diaz and Barry Hart Dubner, 'On the Problem of Utilizing Unilateral Action to Prevent Acts of Sea Piracy and Terrorism: A Proactive Approach to the Evolution of International Law’ (2004-2005) Syracuse J. International L. \& Com, pg 1

3 JN Mak 2006 Unilateralism and Regionalism: Working Together and Alone in the Malacca Straits, Institute of Southeast Asian Studies Singapore pg 104 
associated with corruption, fraud and instability amongst the country's government officials and bureaucrats. Therefore to combat these issues and risks Malaysia is now being forced to seek out and re-allocate resources to improve our ability to protect our water, assets and the people. These costly upgrades usually include new boats, weapons, training, surveillance technology and the costs associated with creating new policies and treaties to aid in the fight against piracy ${ }^{4}$.

Piracy also endangers the lives and welfare of citizens of a variety of flag states, and has a direct economic impact on the global economy in the form of fraud, stolen cargoes, delayed trips and increased insurance premium and financial losses from maritime crime were estimated at \$30-50 billion in $2003^{5}$. The effect would also be the same in the case of other attacks such as armed robbery or sea terrorism.

\section{Environment Implications}

Oil-related disasters at sea are the bane of not only environmentalists but mariners and security specialists as well. They create havoc with the ecology in the maritime environment and have the potential to affect maritime security. The environmental effects are of long-term or short-term duration, but their consequential effects in related maritime spheres can continue over a longer period. ${ }^{6}$ Such attacks would involve collusions, groundings and oil spills. The attacks that could lead to such consequences could be in the form of taking over ships laden with chemicals without competent seamen, intentionally mishandling the ship or also with the ultimate goal to scuttle the ship into an ocean oil rig.

Our oceans are replete with a wide array of saltwater ecosystems which "exists where streams and rivers meet the sea and where tides and

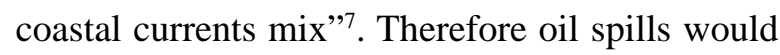
contribute to major threat facing the environment. The coastal zones that are very sensitive to marine pollution include: mangrove forests, coral reefs and river estuaries. Mangrove forests are very rich environments which supports large populations of flora and fauna. Over 50 species of flora and fauna were identified in the mangrove ecosystem of 2 the East Coast of Peninsular Malaysia (Ridwan and De Silva, 1983). The ecosystem was also recognised as an important spawning ground for various types of fish and shrimps. Other than the fish, the marine environment is also the habitat for several endangered wildlife. ${ }^{8}$

Oil spilled into waterways has significant chemical effects on marine environment. For example organisms in the ocean as well as near coastal areas are suffering from the oil spills. They will be endangered in 3 different ways such as by poisoning after ingestion, by coming in direct contact and by destroying entire habitats.

Even after costly and massive cleanup efforts, and along with the passage of years, the negative environmental effect lingers. Because an ecosystem is a synergistic dependent system, where one living thing depends on another, the long lasting effects of this type of impact are gargantuan. In addition to physical harm, humans were also victim to adverse economic consequences by environmental disasters. Many who were fishermen suffered a loss of income in the aftermath of this catastrophic oil spill. Thus the consequences were both environmental and economic in nature ${ }^{9}$.

\section{Political Implications}

The issue of maritime violence was often associated with corruption, fraud and instability amongst the country's government officials and bureaucrats. Lack of any deterrent action by the affected government could result in a boycott of its port facilities. Shippers may take the longer sea routes. The routes may cost more in time but not as much as the inconvenience of losing a cargo to pirates. A nation that relies on safe shipping lanes for a significant portion of its economy will feel

4 Sarahna Wilcox, Maritime Piracy: Implications for the Emerging Market Countries, Emerging Markets Weekly (June 2009) http://sarahna.wilcox@mycmmb.com.

5 Joyce Dela Pena, Maritime Crime in the Straits of Malacca: Balancing Regional and Extra-Regional Concerns.

6 CDR. PK Gosh, Maritime Security Challenges In South Asia and India Ocean: Response Strategies, Honolulu Hawaii. http://www. southchinasea.org

7 NATIONAL CENTERS FOR COASTAL OCEAN SCIENCE http://www.noaa.gov/ecosystems/coastalocean.html

8 Nasiman Sapari, Marine pollution and coastal resources sensitivity index, http://hdl.handle.net/10220/828

9 Leticia Diaz and Barry Hart Dubner, On The Problem of Utilizing Unilateral Action to Prevent Acts of Sea Piracy and Terrorism: A Proactive Approach to the Evolution of International Law, Syracuse J. International \& Com 
the most direct impact. Corruption among elected officials can undermine and weaken political stability $^{10}$.

For example China and Indonesia have been heavily criticized in this area. The author of a recent article in TIME Asia stated the only way President Abdurrahman Wahid could restore credibility to his administration would be to solve the huge problem of piracy. He further acknowledged that it is an open secret in regional shipping circles that rogue elements in the Indonesian military and police have a hand in the problem. The nations of ASEAN are just beginning to seek regional solutions to piracy and put pressure on corrupt officials (Stuart W. Smeard).

When a country's effort in combating piracy is seen not to have resulted in a decrease trend, other countries would have the perception that the enforcement is corrupted, in the sense that the enforcement agencies are having some kind of collaboration with the pirates.

Legal Implications

Negative impact to sea transportation, safety of navigation and marine environment as well as the threat poses to human lives and properties. To curb this problem, we need to strengthen the legal protection of shipping. The maritime piracy and armed robbery against ships have become serious problem for shipping nowadays. According to IMO, piracy reports in 2000 and 2001, summarily, the largest number of attacks had occurred in the Malacca Straits and in the Indonesian waters. There are petty attacks and also serious attacks that had caused human lives and immense danger to the marine environment.

Malaysia should also establish a domestic law on maritime piracy. Malaysia does not have legislation or a provision catering specifically to the crime of piracy and has not incorporated any definition of piracy in domestic legislation. As such, the captured suspects will have to be tried for other crimes that could best fit the bill such as armed robbery, criminal conspiracy or even terrorism if certain elements are met. The law under Courts of Judicature Act 1964 and Penal Code were incorporated to prosecute high sea piracy in Malaysia. And in the recent case with regards to the Somali pirates that have been caught at the Gulf of Eden, they have been charged at the Magistrates Court for arm robbery which is an offence under the
Penal Code under section 392/397.

Such sections read:-

397. Robbery when armed or with attempt to cause death or grievous hurt.

If at the time of committing or attempting to commit robbery, the offender is armed with or uses any deadly weapon, or causes grievous hurt to any person, or attempts to cause death or grievous hurt to any person, such offender shall be liable to be whipped, in addition to any other punishment to which he may be liable under any other section of this Code. And shall be punished under:

392. Punishment for Robbery.

Whoever commits robbery shall be punished with imprisonment for a term which may extend to fourteen years, and he shall also be liable to fine or whipping.

If such act involved the taking of lives of the others, the pirates can be charged under section 302 of the Penal Code which is an offence for murder and if convicted will be sentenced to death.

302. Punishment for murder.

Whoever commits murder shall be punished with death.

If the act involves hostage taking, the relevant section would be:

374A. Hostage-taking.

Whoever seizes or detains and threatens to kill, to injure or to continue to detain another person ("the hostage") to compel the Government of Malaysia or the Government of any State in Malaysia, any other government, or any international organization or any other person or group of persons to do or refrain from doing any act as an explicit or implicit condition for the release of the hostage shall be punished-(a) if the act results in death, with death; and (b) in any other case, with imprisonment for a term of not less than seven years but not exceeding thirty years, and shall also be liable to fine.

The other offences that can be associated with piracy and covered by the Penal Code would be kidnapping, rape and also terrorism. The prosecution of the Somalis pirates for attempted to hijack a Malaysian-owned chemical tanker in the Gulf of Aden, carrying lubricating oil worth approximately 13 million dollars is the first of such case in the Asian country. Therefore we have yet to see the outcome of such case and this will be a landmark case for high sea piracy attacks in this nation. 


\section{Technology Implications}

To combat such acts, we need to strengthen our defense forces especially the navies. The modern pirates and terrorists are highly mobile and equipped with technology and heavy weapons. They can move from the territorial waters of one country to another, or to the high sea, quickly. Therefore we need necessary equipments and vessels to protect our vessels. Due to lack of effective patrol craft and other technological resources will hinder our effort to protect such. And to achieve this we need to equip ourselves with the latest technology which in the end will incur additional costs.

One bright example of this implication is we can see in the year of 2005 and 2006, Malaysia, Singapore and Indonesia; Thailand as observer have entered into an agreement to begin joint air patrols over Malacca Straits in a bid to boost security in the waterway. The aerial patrols, dubbed as 'Eyes in the Sky Plan' will provide valuable supplement to the Trilateral Coordinated Patrols carried out by the navies of the littoral states. One significant advantage of the aerial patrols is that they can be able to fly for up to three nautical miles inside the territorial waters of participating states, thus allowing for reasonable 'transgression' of boundaries. As through sea-patrols the navies were limited to patrolling in their own territorial jurisdiction or high seas.

\section{PROPOSED SOLUTIONS/CONCLUSION}

The America's war on terrorism following 9/11 put the maritime security under the spotlight and prompted the region's states to begin improving security in the maritime domain. This assertive posture must be maintained. Cooperation between the region's states must be enhanced to include agreements on 'hot pursuit' and more mechanisms for intelligence sharing. Major users of the region's waterways must begin to accept a greater responsibility for enhancing maritime security. Japan is one user state that has contributed significantly to efforts to improve safety and security in the Strait of Malacca. And in the death of al-Qaeda leader Osama bin Laden, Malaysia is now beginning to improve its snitch network in the wake of global terror threats. Meaning that, the authorities are going down to the ground to increase intelligence-gathering on any threat. The network is made up of people not on the payroll of security organisations. They are found mainly in border areas, coastal towns, islands and places of public interest. These people would be the eyes and ears for the government to gather information on terrorism, if any.

The Malaysia government also said that the battle against terrorism could be better fought by complementing human resources by highly equipped technology. And also the efforts by the army, navy, air force, police, Maritime Enforcement Agency, Customs, Immigration and other agencies had prevented terrorists' attacks here. According to the Malaysian Maritime Enforcement Agency (MMEA), piracy and armed robbery at Straits of Malacca were very serious especially in the late 1990s. Malaysia had even once listed as war risks' zone by Llyods in 2005. However with the establishment of Maritime Enforcement Agency in 2004 and the launching of the operation of MMEA on $30^{\text {th }}$ November 2005, we could see the decline of piracy acts in the Straits of Malacca. And as of to date, there's no report on maritime terrorism in the Malaysia's maritime zone. Nevertheless the MMEA is still monitoring the maritime zone to avoid such incidents from occurring.

The impact and implication of piracy is great to concerned state. The UNCLOS somehow only gives us a 'western' definition of piracy, thus it limiting the definition of piracy as an illegal act done in high seas, although statistically speaking, it only happen few times compared to armed robbery done in territorial seas. Thus, further amendment to UNCLOS might help relevant states in broadening their powers to detained pirate in their territorial sea. Meanwhile, between states there might be needed some more multilateral agreement to curb the problem of piracy attacks. And also the international waters and territorial seas should have another layer of jurisdiction for the specific crime of terrorism and/or piracy, namely reaction zones and the hot pursuit doctrine should also be extended for those crimes originating in reaction zones as well as for those occurring exclusively on the high seas. ${ }^{11}$ One great quote from St. Augustine, "It was pertinent and true answer which was made to Alexander the Great by a pirate whom he had seized. When the king asked him what he meant by infesting the sea, the pirate defiantly replied: "the same as you do when you infest the whole world; but I do it with a little ship I am called a robber and pirate, and because you do with a great fleet, you are an emperor." 
Books:

\section{REFERENCES}

Adam J. Young, 'Roots of contemporary maritime piracy in Southeast Asia: History, Causes and Remedies, Barnes \& Noble.

Tunku Sofiah Jewa, Public International Law, Vol. II, Pacifica Publications Malaysia, 1996.

R.R. Churchill, A.V. Lowe, The Law of the Sea, $3^{\text {rd }}$ Edition, Juris Publishing Manchester University Press, 1999.

\section{Reports/Conventions:}

Piracy \& Armed Robbery Against Ships Annual Report, ICC International Maritime Bureau 2004.

Malaysia External Statistic Update December 2010, Jabatan Perangkaan Malaysia.

NATIONAL CENTERS FOR COASTAL OCEAN SCIENCE http://www.noaa.gov/ ecosystems/coastalocean.html

Convention for the Suppression of Unlawful Acts Against the Safety of Maritime Security, March 10 1988, 1678 U.N.T.S. 221, 27 I.L.M. 668 (1988).

UNCLOS 1958

\section{Articles/Journals:}

J. Chenevier's Article, 'Piracy under Law of the Sea Convention: Conceptual basis and Practical Limitation.'
Leticia Diaz and Barry Hart Dubner, On The Problem of Utilizing Unilateral Action to Prevent Acts of Sea Piracy and Terrorism: A Proactive Approach to the Evolution of International Law, Syracuse J. International \& Com.

JN Mak 2006 Unilateralism and Regionalism: Working Together and Alone in the Malacca Straits, Institute of Southeast Asian Studies Singapore pg 104

Sarahna Wilcox, Maritime Piracy: Implications for the Emerging Market Countries, Emerging Markets Weekly (June 2009)

Joyce Dela Pena, Maritime Crime in the Straits of Malacca: Balancing Regional and ExtraRegional Concerns, Standford Journal of International Relations Vol. X (Spring 2009)

Nasiman Sapari, Marine pollution and coastal resources sensitivity index, http://hdl. handle.net/10220/828

Stuard W. Smeard, A Thesis on Modern Day Piracy http://www.angelf re.com/ga3/tropicalguy/ piracy-modernday.html

\section{Statutes:}

Penal Code

Newspaper:

The Star, 7th February 2011 